\title{
MALAYSIA-INDONESIA BILATERAL RELATIONS: EMPIRICAL STUDY ON THE STAGE OF KNOWLEDGE OF GENERATION X AND Y INDONESIA AND MALAYSIA
}

\author{
Rohani Hj. Ab Ghani, Ahmad Shukri bin Abdul \\ Hamid, Zulhilmi bin Paidi, Mohd Kasri bin Saidon, \\ Haslinda Hasan, Kamaruddin Ahmad, Muhaemin Latif \\ University Utara Malaysia, University of North Malaysia, \\ University Utara Malaysia, University of North Malaysia, \\ University Utara Malaysia, University Utara Malaysia, State \\ Islamic University (UIN) Alauddin Makassar \\ Email: rag1162@uum.edu.my, shukri@uum.edu.my, \\ zul1085@uum.edu.my,kasri@uum.edu.my, \\ haslynda@uum.edu.my,kama@uum.edu.my. \\ muhaemin.latif@uin-alauddin.ac.id
}

Abstract: Malaysia and Indonesia are traditionally neighboring countries in ASEAN and sharing a historical background, language, culture, and religion. It is undeniable fact that Malaysia-Indonesia relations are often influenced by current national issues such as water territorial, Indonesian immigrants, national product, and others. Reviews These issues always sparked conflicts and Provoked various actions from Indonesians and dieting. Normally, Indonesians are more sensitives compared with dieting when faced with this situation as well. This article focuses on knowledge and understanding of $\mathrm{X}$ and $\mathrm{Y}$ Indonesian generation on Malaysia-Indonesia bilateral relations. This article incorporates the qualitative method with primary data obtained through a questionnaire distributed amongst respondents. Respondents are consisted of UIN's first-degree students and staff $\mathrm{s}$ and were selected by purposive sampling. 
Apart from that, focus group discussion and interview session was held to get a view from respondents. This article found that $\mathrm{X}$ and $\mathrm{Y}$ Indonesian generations have a good understanding of Malaysia. They are also usually aware of the importance of Malaysia-Indonesia bilateral relations. In addition, they acknowledged Malaysia as an essential country for Indonesia's present interest. Respondents also showed high sensitivity regarding competition between Malaysia and Indonesia. The important finding of this writing is both generations $\mathrm{s}$ acknowledge the fact that they are closest neighboring country and a good relationship should be maintained in facing the global challenge

Keywords: Malaysia-Indonesia relationship - national interests - Y Generation - X Generation - UIN Alauddin Makassar

\section{INTRODUCTION}

Indonesia is a neighboring country that has the most similarities with Malaysia compared to other adjacent regions. The similarities in cultural, linguistic, and religious values between Malaysia and Indonesia are influenced by the historical factors of the Malay natural environment that underlie the existence of tamadun in both countries. The similarities that exist have created sentimental value among the people of both countries in the past. This value also binds to the sense of brotherhood among them in the early days of Malaysian independence and also among the older generation in both countries. However, this case is not so significant for the younger generation (in this study they are Generation Y) 
in particular. In Indonesia, Generation Y regards Malaysia as a competitor in all aspects while the older generation, namely Generation X, have almost the same understanding that Malaysia is Indonesia's main competitor, in fact, they also accuse Malaysia of stealing ideas for Indonesian national products. However, nowadays economic and political developments between nations which increasingly show the need for elements of wise partnership require people in both countries to think again about the type of relationship that can be fostered even at the same time, Malaysia-Indonesia even though at the same time, both -two countries still maintain their national interests. In harmony with this case, knowledge of the people in the country needs to be examined to determine whether the phase of knowledge affects their understanding of Malaysia. This investigation provides the foundation for the knowledge level of Generation X and Y of Indonesia in understanding their country's two-way relationship with Malaysia.

\section{STUDY PROBLEMS}

The history of Malaysia-Indonesia relations is a relationship between two countries which is based on common interests, embroidered by elements of cognate nations, equality of religion, culture, and language. These factors have put Indonesia as a neighboring country that has a special relationship with Malaysia.

However, even though the two countries have mutual interests, Indonesia-Malaysia relations often face conflicts. 
Since a decade ago, Indonesia has often raised questions about the creation of batik patterns, dance issues, soccer matches, the Terang Bulan song, and several other issues that have become the cause of the emergence of hot issues in relations between the two countries. In addition to national issues, matters that are personal as the son of a royal household crisis that is Tengku Temenggung Kelantan, Tengku Fakhry and berkerakyatan American model of Indonesia - Indonesia namely Manohara Odelia Pinot underlying conflict helped these two countries. In addition, the relationship between the two countries was hilarious due to the criticism of Zainuddin Maidin, who is a Malaysian political expert against the former Indonesian leader, BJ Habibie, who also became an issue in Malaysia-Indonesia relations (Sandro Gatra, 2012). Because of that, a group of young Indonesians held a demonstration against Malaysia following the criticism. This case is still called for in the events column in Figure. id (2020) as "Hate towards Indonesia is like ingrained, Malaysian politicians mock BJ Habibie wants to dissolve the Republic of Indonesia because of the case of Timor Leste".

In comparison, Gen $\mathrm{Y}$, which is the younger generation, is more responsive to issues involving Malaysia compared to Gen X, which is the older group. Generation Y's critical attitude towards Malaysia was demonstrated through demonstrations held in Indonesia's main capitals. For example, demonstrations were launched by a group of young people who staged their group as FLAG or the Fortress of 
People's Democracy. Although their attitude does not represent the Indonesian kingdom, this action is seen as an unhealthy matter in the relationship between the two countries (Utusan Malaysia, 2012). The reason given by the government is that the attitude shown by the younger generation is the result of excessive coverage by the Indonesian media which is freer than the Malaysian mass media. Apart from that, the issue of Indonesian people's nationalism is said to be very high also influenced their approach to issues related to Malaysia. The connection between their attitude and the spirit of patriotism and nationalism was discussed by a Malaysian journalist in Indonesia, namely Saharudin Mustafa who among other things stated, the spirit and spirit of Pancasila in the souls of the Indonesian people which is too thick has caused more than 234 million people of that country to be too proud of their country. The identity of the Indonesian people to defend the sovereignty of their country knows no age limit, position, or color. Saharudin further stated;

As long as the name is the Indonesian nation, that's when the people of this country will work for hand in hand to ensure that the sovereignty of Pancasila is upheld. Even though living in an era of openness and democracy are not borderline, but compassion for the country precedes everything (Malaysian Week, 2012).

Indonesian people, especially Gen Y, often see their country's issues in a national context, especially when dealing 
with Malaysia. In general, the Indonesian media is the champion in every issue that arises in the relationship between Malaysia and Indonesia. This is because people's perceptions are heavily influenced by the news published by the Indonesian mass media. Every sensitive issue relating to Malaysia has been manipulated by the country's mass media for market reasons to sell and increase the number of sales and ratings of Indonesian newspapers (Rohani, 2013).

Ironically, the opposite approach was shown by Generation X to groups of Malaysians there. A warm, respectful and respectful greeting is often seen in any Malaysian visit to the country. Is it because of the experience of friendship with peers of the same age in Malaysia, a deeper understanding of Malaysia-Indonesia relations causes them to be more mature in dealing with issues related to Malaysia.

On the other hand, in Malaysia too, Generation Y rarely reacts excessively in this country when dealing with issues related to Indonesia. There are not a few issues raised by the Indonesian side that are directly related to Malaysia. Regarding Malaysian girls who were taken away by Indonesian youths, the jerebu issue, the death of Malaysian students as a result of fighting with criminals in Indonesia, the attack by a group of residents on the Malaysian embassy building in Jakarta did not spark a demonstration by Malaysian youth against the Indonesian monarchy. Whether they are calm or not, this story is influenced by their lack of knowledge about issues that link their country to Indonesia or they lack the 
spirit of patriotism compared to the Indonesian people. Paradoxically, in all the oppositions by some of the Indonesian population to Malaysia, there are more people than those who infiltrate the country.

This situation raises the question among observers of relations between the two countries. As stated by Ahmad Nizar (2013), where is the problem with Malaysia-Indonesia relations, because the more cooperation that exists, the more frequent conflicts will arise. Therefore, many researchers link this case to several other issues such as the political environment, sense of entitlement, global economic competition, and several other matters that need to be investigated in assessing the level of knowledge and understanding that affects the perception of Generation $\mathrm{Y}$ and $\mathrm{X}$ Indonesia towards their country's relationship. with Malaysia.

\section{LITERATURE REVIEW}

Malaysia-Indonesia relations have become the focus of many scholars such as Harrison, (1964). Ismail, (1984) and Koentjaraningrat (1975). They each argue that the Malay culture in the archipelago is the core of the characteristics of the state and nation in the Malay Archipelago region which previously were united under one political entity. This element also formed the Malay civilization in Malaysia and Indonesia in the modern history of both countries (Nik Anuar Nik Mahmud, 2000). This case embodies a uniqueness in the 
relationship between Malaysia and Indonesia, which is a traditional relationship based on the value of belonging from the point of view of the same ethnic group, cultural and religious equality. This particular form of relationship has been called by several names by writers such as "one kin twonation" by Joseph Chin Liow (2005), " like an aura with a cliff ” by Kunnaselan (1999), Brackman (1963), (Mackie, 1974). and also Easter (2002) characterizes the Malaysian-Indonesian people in the context of the relationship of "fellow brothers " who share history, culture, and religion.

In the early days of Malaysia's independence, Indonesia contributed a lot to Malaysia's social progress, especially in the fields of education and culture. In the Malaysia-Indonesia Bilateral Cooperation Agreement in Education and Culture on January 26, 1967, the two countries have agreed on the following matters:

\section{ARTICLE I}

\section{General}

The Indonesian Delegation and the Malaysian Delegation agreed that to accelerate the development process towards achieving the simultaneous aspirations of the people of the two countries, there needs to be close cooperation between the governments of the two countries in 
Malaysia-Indonesia Bilateral Relations: Empirical Study on the Stage of....

implementing various programs in the education sector ( ANM 2003/0008933 , 1967 ).

In this agreement, provisions have been reached for cooperation in the aspects of the exchange of teachers and educators, textbooks and magazines as well as the exchange of investigative officers, lecturers, students, and trainers. The manifestation of such cooperation also shows Indonesia has provided the school faculty to study ranked Certificates and diplomas in schools and universities in Malaysia in the 1970's era. The culmination of this collaboration was the involvement of Indonesia in the effort to establish the Universiti Kebangsaan Malaysia (UKM) in 1970. Indonesia's contribution in this case was a symbol of their strong support for the struggle for the dignity of the Malay language in Malaysia at that time. Appreciation for Indonesia's efforts in the advancement of Malaysian education was expressed by Professor Dr. Mahmud Mohd Nor, the former Dean of the SME Medicine Faculty in 1989 stated; "One thing that cannot be forgotten is that we are indebted to Indonesia for donating teaching staff to the Faculty of Medicine." (Rohani, 2009). The theme of this collaboration is also manifested in the language aspect if Balai Pustaka, Indonesia makes a major contribution to the development of the Malay language in Malaysia. Another framework of cooperation relations is clearly in the language field. Since 1970 - late again the close cooperation between Indonesia and Malaysia have been run over the aspiration to restore the glory of the Malay language 
in this archipelago. In this era, the slogan "keserumpunan" is the main attraction in Indonesia-Malaysia relations.

While many talks about Indonesia's contribution to Malaysia's early development, many do not realize that Malaysia has made a big contribution to the Indonesian people to build a life in this country. According to Khazin Mohd Tamrin (1974), the narrowness of life and the problems of war and hostility with the Dutch colonialists had caused the Indonesian people, especially those around the island of Java, to emigrate to Malaya. Likewise, the Minangkabau , Banjar, Kampar and others have settled in Negeri Sembilan, Kedah, Perak, Pahang, Selangor and Johor . Their migration on a large scale at once has changed the demographics of Malaysia and helped shape the diversity of cultures.

Malaysia's economic growth is better than Indonesia's, this country is the foundation for Indonesian citizens to come to work in this country. Improvements in living standards and a better education system have changed the local community's perception of the type of work. In connection with this scenario in the form of employment forms of employment are not proficient and proficient half is no longer a party of the people of Malaysia pedestal and blanks are largely filled by Labor Indonesia ( TKI) from Indonesia. The arrival of Indonesian Migrant Workers Since the early 1970s, countries in Malaysia such as Sabah, which are directly adjacent to Kalimantan, have given a political, economic, and social impression to the region (Azizah Kassim, 1998). 
Furthermore, in era 1990 - an exhibit a million migrant workers flooded Malaysia both valid and invalid to seek employment migrant workers who enter Malaysia illegally invoked as Undocumented Foreign Immigrants (PATI). The issue of PATI later became a major problem in MalaysiaIndonesia relations and was characterized by Mak Jum Num (2000) as a thorn in the flesh in relations between the two countries.

In the history of Malaysia-Indonesia relations, more and more issues have emerged that have sparked conflict between the two. It is undeniable that Indonesia is a neighboring country that is most similar to Malaysia in terms of religion, nation, and culture. However, Indonesia was also the only country that had a confrontation with Malaysia which sparked the armed conflict in 1963-1966. Although the conflict between the two countries was successfully resolved, the conflict between the two countries always alternated with cooperation. As stated in the previous section, issues of overlapping borders, national products such as batik, the issue of the Malaysian national anthem, and the National Anthem which were accused of being taken from an Indonesian anthem have caused anger among the Indonesian people. He was also added to the issue of the marriage of Indonesian girls with high-profile individuals in Malaysia and also the issue of an inverted Indonesian flag that had occurred in the Southeast Asian Sports theme held in Kuala Lumpur in 2017. This applies if the proponent has made a mistake in printing a program book that contains an inverted Indonesian flag. This 
case caused anger among the Indonesian people. Khairi Jamaluddin then offered an open apology to the Minister of Youth and Sports of Indonesia, Imam Nahrawi, which read, among other things, " Mr. Imam, please accept my sincere apologies for this mistake ... "Actually there was no malicious intent. I am very upset with this mistake. Sorry, " he said, also pengerusi Proponents championship business SEA Games 2017 (Masoc) (Malaysiakini, 2017).

In comparison, the Indonesian people, especially Gen Y, seem very emotional when dealing with issues involving Malaysia. For example, in 2009 a demonstration was held by a group of Indonesians who disputed an advertisement aired on the Discovery Channel which stated that the Pendet dance, which originated on the island of Bali, was Malaysian. Demonstrators have chanted the words "Destroy Malaysia", burned the Malaysian flag, threw rotten eggs at the Malaysian Embassy building in Jakarta, and others. The head of this group, known as Mustar Bona Ventura, who is a student activist at the Indonesian Christian University, accused Malaysia of frequently stealing and piracy of Indonesian property. In connection with this, they have also opened registration for the Indonesian people to become volunteers for the People's Democratic Fortress (BENDERA) and are willing to face all possibilities with Malaysia, including a willingness to go to war. This action brought fear to the number of Malaysian students who were in the country. 
In many circumstances, the Indonesian people, especially among the younger group or generation $\mathrm{Y}$, are seen as very responsive and sometimes aggressive towards Malaysia when issues arise related to their country. Their attitude and approach towards Malaysia can be seen clearly through social media such as Facebook, Twitter, Tumblr, Snapchat, Instagram, and others. Bad and disrespectful words addressed to Malaysia show that Indonesian Gen Y does not respect Malaysia.

In this regard, the role of the mass media, especially in Indonesia, is seen as very significant (Rohani, 2013). In the context of distributing information regarding current issues related to Malaysia (and other countries), private newspapers in Indonesia are free to broadcast news. The selection of sensational news tries to sell their newspapers. Negative news about relations with Malaysia gives a negative natijah to the people's view of Malaysia. Every time an issue arises, social media will win this atmosphere. Just click on the words Malaysia-Indonesia, Destroy Malaysia, or Malingsia, criticism, and ridicule will appear from both parties. Under the social media platform that is the field for the people of both countries, the majority of those involved are Generation Y.

In general, Gen $\mathrm{Y}$ in both countries are involved in reacting to issues of both countries, but in comparison, Indonesian Gen Y is more active, sensitive, and sometimes even aggressive in dealing with issues with Malaysia (Rohani et al. 2019). When Generation Y in Malaysia, rarely often 
accentuate the aggressive reaction against the people of Indonesia as reprisals against young people their provocative actions against Malaysia.

Behind this situation, the opposite situation prevails among Gen X in the country that seems familiar with Malaysia. The family attitude is clearly shown by them no matter what the circumstances. It turns out that the sentiment of a group of one nation, religion, and culture towards Malaysia is still thick among Gen X compared to Gen Y.

After more than six decades of bilateral relations between the two countries, it is hoped that more efforts will be carried out by the two countries to seek the principle of understanding of the Indonesian people regarding state relations between Indonesia and Malaysia. This research is also important to identify the factors that contribute to the level of knowledge of the Indonesian people about Malaysia in particular about the ongoing relationship between the two countries. This effort is important in providing added value to strengthen the existing relations between the two countries.

\section{METHODOLOGY}

This study uses qualitative methods with a triangulation approach with a focus on library studies, surveys, interviews, and focus group discussions. Primary data was collected through the distribution of research questions to respondents. They consisted of administrative and academic 
staff as well as UIN students representing two generations, namely $\mathrm{X}$ and $\mathrm{Y}$. The research questions were formed to obtain information about the factors and perceptions that influence respondents about Malaysia-Indonesia relations. The research questions were circulated to respondents who were selected by purposive sampling. As many as 199 respondents were selected from the entire student population and UIN management accomplices aged 20 to 60 years. The selected respondents and study subjects are administrative and academic accomplices and those who are currently attending lectures at UIN from various programs. The selection of samples and study locations determined at UIN is based on the suitability of the objectives of the investigation. The research questions are formed based on the highlights of works based on issues that are often broadcast in newspapers, social media, and previous studies.

Primary data was also obtained through focus group discussion and retrieval gab also held in the selected respondents. Apart from that, the views of a collection of experts in Malaysia-Indonesia relations were obtained through the interview sessions that had been held. The data obtained are processed as study results. In addition, the multiple case study approach is considered appropriate because of the 'rich data' that can provide investigators with an in-depth look into the life experiences of participants. In this context, study data were collected using various types of data collection techniques (observation, interview, and field notes). The data collected contains the views, perceptions, 
experiences, or ideas of individuals related to the case. The use of various perspectives and various types of data collection in case studies can do two things, namely improving the quality of the study and lending weight to the validity of the findings (Hamilton, 2011).

At the same time, the gap between studies will be obtained through a library study whether on the records referred to in the Malaysian Archives which refer to the history of Malaysia-Indonesia relations. While secondary sources are also information obtained from books, journal articles, newspaper reports in both countries, and online materials.

The research questions are divided into five parts, namely:

Part A: Demographics of Respondents

Part B: Information About Malaysia

Part C: Understanding Malaysia

Part D: Perception of Malaysia-Indonesia Relations

The data obtained through the research questions have been analyzed using the Statistical Packages for Social Sciences version 16.0 (SPSS 16.0). For the descriptive discussion, statistical analyzes such as frequency, min, and hundredth analysis were applied. Apart from that, the appropriate statistical test used for this study is the independent sample t-test (independent sample t-test) to produce an overall 
picture and statistical formulation of the different views of two categories of respondents, namely Gen X and Gen Y, which are the focus of this study.

\section{SCOPE AND LIMITATIONS OF THE STUDY}

This study focuses on Generations $\mathrm{X}$ and $\mathrm{Y}$ at the

State Islamic University, Alauddin, Makassar, Indonesia (UIN). Respondents comprised of Generation X comprises than stooge who consists of administrator and lecturers when Generation $\mathrm{Y}$ is also comprised of students in the baccalaureate diploma ranked. The focus of the study is also to examine the stage of knowledge and understanding of the two generations about the two-way relationship between Malaysia and Indonesia. By the way, the elements that affect this stage of knowledge and helped an understanding taken something like a factor of media, peer-review, and role of the university stakeholders.

\section{GET STUDY AND DISCUSSION}

i. Demographic Analysis

A portion in the matter inquired contains items that highlight I intimation demography study respondents. There are four items in this section, namely gender, age, area of origin, and marital status. 
Rohani Hj. Ab. Ghani, Ahmad Sukri bin Abdul Hamid, Zulbilmi bin Paidi...

ii. Gender

Then the overall 199 respondents involved in this study They are comprised of 95 people or $47.7 \%$ comprised of male respondents when crowded as 98 people or $49.2 \%$ are re s Ponden women. As many as six people or 3\% did not state their gender status. The relevant data are presented in Table 1.

Table 1 - Distribution of Respondents by Gender

\begin{tabular}{|l|r|r|}
\hline \multicolumn{1}{|c|}{ Gender } & N & Hundred \\
\hline Man & 95 & 47.7 \\
\hline girl & 98 & 49.2 \\
\hline Not stated & 6 & 3.0 \\
\hline amount & $\mathbf{1 9 9}$ & $\mathbf{1 0 0 . 0}$ \\
\hline
\end{tabular}

iii. Age

In terms of age distribution, the majority of respondents consisted of those aged 21 years, namely 44 people or $22.1 \%$, followed by respondents aged 22 years as many as 39 people or $19.6 \%$, and so on, respondents aged 23 years which amounted to 17 people or $8.5 \%$. and respondents aged 20 years, amounting to 14 people or $7 \%$. Overall, all of them are in the age category between 20 and 23 years, representing the majority, namely 114 people or $57.2 \%$ of all 199 respondents. Table 4.2 describes data that has been 
categorized according to the age range. Based on the schedule, the number of respondents who are categorized as Gen $\mathrm{X}$ and Gen $\mathrm{Y}$ is 49 and 146 people, respectively, or in terms of the percentages are $24.6 \%$ and $73.4 \%$. In addition, as many as 4 respondents, or $2 \%$ did not state their age in the inquiry form.

Table 2 - Distribution of Respondents by Age

\begin{tabular}{|l|l|l|l|}
\hline \multicolumn{2}{|l|}{ Category Age (Years) } & N & Hundred \\
\hline $\begin{array}{l}\text { Gen } \\
\text { Y }\end{array}$ & $1-29$ & 146 & 73.4 \\
\hline $\begin{array}{l}\text { Gen } \\
\text { X }\end{array}$ & 30 and up & 49 & 24.6 \\
\hline Not stated & 4 & 2.0 \\
\hline amount & $\mathbf{1 9 9}$ & $\mathbf{1 0 0 . 0}$ \\
\hline
\end{tabular}

iv. Place of Origin

The respondents involved in this study consisted of those who came from all over Indonesia. However, if you look at the distribution, the majority of them are from Makassar, namely 41 people or 20.6\%, Gowa as many as 16 people or $8 \%$, Bulukumba as many as 14 people or $7 \%$, Bone as many as 10 people or 5\%. The remaining 118 people or $58.4 \%$ came from other regions as stated in Table 3.

Table 3 - Distribution of Respondents by Region of Origin 
Rohani Hj. Ab. Ghani, Abmad Sukri bin Abdul Hamid, Zulbilmi bin Paidi...

\begin{tabular}{|l|l|l|}
\hline Area & $\mathbf{N}$ & Hundred \\
\hline Makassar & 41 & 20.6 \\
\hline Gowa & 16 & 8.0 \\
\hline Bulukumba & 14 & 7.0 \\
\hline Bone & 10 & 5.0 \\
\hline Etc & 118 & 58.4 \\
\hline amount & $\mathbf{1 9 9}$ & $\mathbf{1 0 0 . 0}$ \\
\hline
\end{tabular}

v. Marital Status

Also highlighted in the demographic section is the announcement of marital status. Table 4.4 describes the distribution of respondents according to the status. The majority of respondents consist of those who are not married, which is as many as 147 people or $73.9 \%$, while those who are married are 45 people or $22.6 \%$. Seventeen respondents or $3.5 \%$ did not state their marital status.

Table 4 - Distribution of Respondents by Gender

\begin{tabular}{|l|l|l|}
\hline Marital Status & N & Hundred \\
\hline Not married & 147 & 73.9 \\
\hline get married & 45 & 22.6 \\
\hline Not stated & 7 & 3.5 \\
\hline
\end{tabular}




\begin{tabular}{|l|l|l|}
\hline Marital Status & N & Hundred \\
\hline amount & 199 & 100.0 \\
\hline
\end{tabular}

\section{FINDINGS}

The courant is discussing descriptive study data analysis. The analysis was made by looking at the response scores obtained from each item contained in the inquiry form. As mentioned in the previous section, the items involved consist of three (3) parts in the research questions, namely Part B which contains items related to the respondent's background knowledge about Malaysia, Part C which measures the stage of respondents' understanding of issues related to Malaysia and Courant D look to the respondent's perception of half of the flower of Malaysia-Indonesia.

\section{i. Background Knowledge About Malaysia}

Table 5 describes the data obtained from Part B in the research questions. Part $B$ contains items about the background knowledge of Indonesian respondents about Malaysia. In general, the items contained in this section examine the extent to which respondents know (familiar) about Malaysia as a neighboring country. All of these items aim to produce a descriptive picture of the respondent's background about Malaysia. Like the data listed in Table 4.5, this discussion will also analyze the comparison of responses 
received based on the categories of Gen X and Gen Y respondents.

The first item highlights information from respondents about the existence of friends in Malaysia. The analysis found that the majority of respondents had friends in Malaysia. The data shows that those who agree and strongly agree with this item are as many as 102 people. In detail, Gen $\mathrm{X}$ consists of $52.1 \%$ or as many as 25 people (agree) followed by $8.3 \%$ or 4 people (strongly agree). While Gen Y was as busy as 55 people $(37.9 \%)$ and followed by 18 respondents $(12.4 \%)$ who stated that they strongly agreed.

In addition to the presence of friends, respondents were also asked to state whether they have family who works in Malaysia. The number of respondents who stated that they agreed and strongly agreed with this item was as many as 100 people. Of this number, respondents in the Gen X category consist of $47.9 \%$ or as many as 23 people (agree) followed by $6.3 \%$ or 3 people (strongly agree). While Gen Y was as busy as 44 people (30.3\%) and followed by 30 respondents (20.7\%) who stated they strongly agreed.

Meanwhile, the number of Indonesian respondents who received information through newspapers in their country regarding Malaysia, namely those who agreed and strongly agreed, was as many as 125 people. In detail, Gen X consists of $51.1 \%$ or as many as 24 people (agree) followed by $35.2 \%$ or 51 people (strongly agree). While Gen $\mathrm{Y}$ as many as 
46 people $(31.7 \%)$ are uncertain and followed by 51 respondents $(35.2 \%)$ who stated that they agreed.

Apart from that, Indonesian respondents who followed developments about Malaysia through social media consisted of a group of Gen X who gave an uncertain view, namely $41.3 \%$ or as many as 19 people followed by $39.1 \%$ or 18 people (agree). While Gen Y as many as 41 people (28.5\%) are uncertain and followed by 52 respondents (36.1\%) who stated that they agreed.

Regarding their views on hearing (getting) positive information about Malaysia. The number of respondents who stated that they agreed and strongly agreed was as many as 142 people. In detail, Gen X consists of $83.7 \%$ or as many as 41 people (agree) followed by $6.1 \%$ or 3 people (strongly agree). While Gen Y was as busy as 63 people (43.4\%) and followed by 35 respondents $(24.1 \%)$ who stated that they strongly agreed.

Regarding information about Malaysia provided by universities in their country, $46.9 \%$ Gen $\mathrm{X}$ or as many as 23 people (agree) followed by $28.6 \%$ or 14 people (uncertain). While Gen Y as many as 55 people $(38.2 \%)$ was uncertain and followed by 55 respondents $(29.2 \%)$ who stated that they agreed. 
Rohani Hj. Ab. Ghani, Abmad Sukri bin Abdul Hamid, Zulbilmi bin Paidi...

Table 5 - Background Knowledge of Malaysia

\begin{tabular}{|c|c|c|c|c|c|c|c|c|c|c|c|c|c|c|}
\hline \multirow{2}{*}{$\underset{\overrightarrow{0}}{\overrightarrow{5}}$} & \multirow{2}{*}{ Statement } & \multirow{2}{*}{$\begin{array}{l}\text { } \\
\stackrel{0}{E}\end{array}$} & \multicolumn{2}{|c|}{$\begin{array}{l}\text { Strongly } \\
\text { Disagree }\end{array}$} & \multicolumn{3}{|c|}{$\begin{array}{l}\text { Not } \\
\text { Agree }\end{array}$} & \multirow{2}{*}{\begin{tabular}{|c|} 
No \\
$\mathrm{t}$ \\
Cer \\
tai \\
nly \\
$\%$
\end{tabular}} & \multicolumn{2}{|c|}{ Agree } & \multicolumn{2}{|c|}{$\begin{array}{l}\text { Very } \\
\text { Agree }\end{array}$} & \multicolumn{2}{|c|}{ amount } \\
\hline & & & $\mathbf{N}$ & $\%$ & $\mathbf{N}$ & $\%$ & $\mathbf{N}$ & & $\mathbf{N}$ & $\%$ & $\mathbf{N}$ & $\%$ & $\mathbf{N}$ & $\%$ \\
\hline \multirow{2}{*}{ B1 } & \multirow[t]{2}{*}{$\begin{array}{l}\text { I have friends in } \\
\text { Malaysia }\end{array}$} & $\mathbf{X}$ & 5 & 10.4 & 8 & 16.7 & 6 & 12.5 & 25 & 52.1 & 4 & 8.3 & 48 & $\begin{array}{c}100 . \\
0\end{array}$ \\
\hline & & $\mathbf{Y}$ & 17 & 11.7 & 29 & 20.0 & 26 & 17.9 & 55 & 37.9 & 18 & 12.4 & 145 & $\begin{array}{c}100 . \\
0\end{array}$ \\
\hline \multirow{2}{*}{ B2 } & \multirow[t]{2}{*}{$\begin{array}{l}\text { I have a family who } \\
\text { works in Malaysia }\end{array}$} & $\mathbf{X}$ & 6 & 12.5 & 12 & 25.0 & 4 & 8.3 & 23 & 47.9 & 3 & 6.3 & 48 & $\begin{array}{c}100 . \\
0\end{array}$ \\
\hline & & $\mathbf{Y}$ & 21 & 14.5 & 27 & 18.6 & 23 & 15.9 & 44 & 30.3 & 30 & 20.7 & 145 & $\begin{array}{c}100 . \\
0\end{array}$ \\
\hline \multirow{2}{*}{ B3 } & \multirow[t]{2}{*}{$\begin{array}{l}\text { My ancestors are } \\
\text { from Malaysia }\end{array}$} & $\mathbf{X}$ & 17 & 36.2 & 23 & 48.9 & 5 & 10.6 & 1 & 2.1 & 1 & 2.1 & 47 & $\begin{array}{c}100 . \\
0\end{array}$ \\
\hline & & $\mathbf{Y}$ & 61 & 42.4 & 56 & 38.9 & 17 & 11.8 & 6 & 4.2 & 4 & 2.8 & 144 & $\begin{array}{c}100 . \\
0\end{array}$ \\
\hline \multirow[t]{2}{*}{ B4 } & \multirow{2}{*}{$\begin{array}{l}\text { I often read news } \\
\text { about Malaysia } \\
\text { through Indonesian } \\
\text { newspapers }\end{array}$} & $\mathbf{X}$ & 2 & 4.3 & 4 & 8.5 & 13 & 27.7 & 24 & 51.1 & 4 & 8.5 & 47 & $\begin{array}{c}100 . \\
0\end{array}$ \\
\hline & & $\mathbf{Y}$ & 4 & 2.8 & 32 & 22.1 & 46 & 31.7 & 51 & 35.2 & 12 & 8.3 & 145 & $\begin{array}{c}100 . \\
0\end{array}$ \\
\hline B5 & $\begin{array}{l}\text { I often follow } \\
\text { developments about }\end{array}$ & $\mathbf{X}$ & 2 & 4.3 & 4 & 8.7 & 19 & 41.3 & 18 & 39.1 & 3 & 6.5 & 46 & $\begin{array}{c}100 . \\
0\end{array}$ \\
\hline
\end{tabular}


Malaysia-Indonesia Bilateral Relations: Empirical Study on the Stage of....

\begin{tabular}{|c|c|c|c|c|c|c|c|c|c|c|c|c|c|c|}
\hline & $\begin{array}{l}\text { Malaysia through } \\
\text { social media }\end{array}$ & $\mathbf{Y}$ & 4 & 2.8 & 34 & 23.6 & 41 & 28.5 & 52 & 36.1 & 13 & 9.0 & 144 & $\begin{array}{c}100 . \\
0\end{array}$ \\
\hline \multirow[b]{2}{*}{ B6 } & \multirow{2}{*}{$\begin{array}{l}\text { I often follow } \\
\text { developments about } \\
\text { Malaysia through my } \\
\text { family and friends } \\
\text { from my country } \\
\text { who have become } \\
\text { residents of Malaysia }\end{array}$} & $\mathrm{X}$ & 4 & 8.3 & 5 & 10.4 & 11 & 22.9 & 25 & 52.1 & 3 & 6.3 & 48 & $\begin{array}{c}100 . \\
0\end{array}$ \\
\hline & & $\mathbf{Y}$ & 23 & 15.9 & 34 & 23.4 & 32 & 22.1 & 45 & 31.0 & 11 & 7.6 & 145 & $\begin{array}{c}100 . \\
0\end{array}$ \\
\hline \multirow{2}{*}{ B7 } & \multirow[t]{2}{*}{$\begin{array}{l}\text { I often hear positive } \\
\text { information about } \\
\text { Malaysia }\end{array}$} & $\mathbf{X}$ & 1 & 2.0 & 1 & 2.0 & 3 & 6.1 & 41 & 83.7 & 3 & 6.1 & 49 & $\begin{array}{c}100 . \\
0\end{array}$ \\
\hline & & $\mathbf{Y}$ & 2 & 1.4 & 12 & 8.3 & 33 & 22.8 & 63 & 43.4 & 35 & 24.1 & 145 & $\begin{array}{c}100 . \\
0\end{array}$ \\
\hline \multirow[t]{2}{*}{ B8 } & \multirow{2}{*}{$\begin{array}{l}\text { My university } \\
\text { provides a lot of } \\
\text { information about } \\
\text { Malaysia }\end{array}$} & $\mathbf{X}$ & 0 & 0.0 & 8 & 16.3 & 14 & 28.6 & 23 & 46.9 & 4 & 8.2 & 49 & $\begin{array}{c}100 . \\
0\end{array}$ \\
\hline & & $\mathbf{Y}$ & 10 & 6.9 & 27 & 18.8 & 55 & 38.2 & 42 & 29.2 & 10 & 6.9 & 144 & $\begin{array}{c}100 . \\
0\end{array}$ \\
\hline
\end{tabular}

\section{ii. Understanding About Malaysia}

Table $\mathrm{C}$ shows the respondent's understanding of Malaysia. Their reading of Malaysia through local newspapers shows that Gen X (42.9\%) is uncertain while Gen Y (33.1\%). Followed by disagreeing that is Gen X (32.7\%) while Gen Y is higher that is $39.7 \%$. The lowest percentage is strongly agreed which is $4.1 \%$ for Gen $\mathrm{X}$ and Gen $\mathrm{Y}$ is $1.5 \%$. 
Rohani Hj. Ab. Ghani, Ahmad Sukri bin Abdul Hamid, Zulbilmi bin Paidi...

While the second item, which also shows that respondents are uncertain, is $34.7 \%$ for Gen $\mathrm{X}$ and followed by Gen $\mathrm{Y}$, which is $31.3 \%$. The hundred for items shows a balance between the stages of understanding, namely disagree, uncertain, and agree, namely (22.4\%), (34.7\%) and (22.4\%) for Gen X. Meanwhile, for Generation Y, hundreds of understanding stages are also in the same pattern. However, the uncertain understanding stage shows the highest percentage, which is $31.3 \%$, followed by $28.4 \%$ for the disagree stage, while the lowest percentage is $6.0 \%$ strongly agree. In comparison, the percentage of strongly agree for Gen $\mathrm{X}$ and $\mathrm{Y}$ does not show a big difference, but Gen $\mathrm{Y}$ has a higher level of approval compared to Gen X which is 2.0\%.

For the third item, which is asking and discussing faceto-face with colleagues from Malaysia, it shows that Gen Y respondents have a higher level of strongly disagree, which is $59.7 \%$, followed by disagreeing at $17.9 \%$ and strongly agreeing at $3.0 \%$. While Gen $\mathrm{X}$ also the highest percentage is uncertain, namely $30.6 \%$, disagree $28.6 \%$ and strongly agree only $2.0 \%$.

Meanwhile, for items asking and discussing with friends from Malaysia online (online) it shows the same level of understanding for generations $\mathrm{X}$ and $\mathrm{Y}$, namely for the stage of strongly disagreeing and disagreeing is more dominant, namely Gen X (22.9\%). ) for strongly disagree and also disagree is $(31.3 \%)$. While Gen $Y$ showed a larger number for the understanding stage, strongly disagree, namely $41.9 \%$ 
and followed by uncertainty as much as $25.0 \%$. For items reading history books and Malaysian society, it shows that Generation $\mathrm{Y}$ is dominated by $37.0 \%$ strongly disagree and $35.6 \%$ disagree. While Generation X, 46.9\% disagree and $32.7 \%$ are not sure.

For items reading and trying to get information about Perdana Malaysia (Dato' Seri Najib Tun Abdul Razak), it shows a pattern of understanding of the previous item, namely for Gen $Y$ still showing dominance in the understanding stage, strongly disagree, which is $46.7 \%$ followed by disagreeing as much as $25.2 \%$. Meanwhile, for Gen X, 33.3\% disagree and 31.3\% are uncertain. Meanwhile, the level of strongly agree is $2.1 \%$ for Gen $\mathrm{X}$ which shows the lowest stage compared to Gen $\mathrm{Y}$ as much as $2.2 \%$.

For the item looking at train models from Malaysia such as Proton, Gen Y gave a view of strongly disagreeing $45.2 \%$, while respondents who did not agree were also $20.7 \%$. For Gen X also as much as $28.6 \%$ strongly disagree followed by disagreeing as much as $20.7 \%$. For the uncertain stage as much as $21.5 \%$ for Gen Y while 30.6\% for Gen X in the same category.

Regarding the item read information about Dr. Mahathir Mohamad, as much as $65.4 \%$ for Gen $\mathrm{Y}$ while disagreeing is $18.8 \%$. For Gen $\mathrm{X}$ too, the majority is uncertain, namely $42.9 \%$ followed by $22.4 \%$, which is agreed and also agree. 
Rohani Hj. Ab. Ghani, Abmad Sukri bin Abdul Hamid, Zulbilmi bin Paidi...

\section{DISCUSSION}

The Malaysia-Indonesia two-way relationship is a form of link that is not only geopolitical. The interrelationship that exists between the two countries has a socio-cultural and historical significance which is no less important in the context of the independence of the two countries and their people who share their family and lineage. However, with the circulation of the times and times, changes in terms of appreciation of history and the value of transportation based on the equality of national families are often unavoidable. This case was acknowledged by the well-known analyst of Indonesia's foreign policy, Zainuddin Djafar, with a cynical view that the relationship of past generations no longer has sentimental value among the people of Indonesia and Malaysia. This matter was raised in a discussion in Indonesia that reviewed Malaysia's actions on the Ambalat issue; "They don't worry about the past. The triumph of Indonesia has closed the book in their eyes, no longer the term brothersister, elder brother. (http://nasional.kompas.com/read/2010/08/30/19132967/ Malaysia.Takut dengan. Indonesia). " Coupled with the existence of various elements that often encourage the thinking of the people of the two countries towards the perception of differences versus similarities, the gap between the citizens of the two countries will become even more pronounced. Thus, to address the prospect of this widening gap, this study places a comparative analysis of the level of knowledge about the Malaysia-Indonesia two-way 
relationship among citizens of different generations as one of its objectives.

The previous discussion showed a positive trend in terms of knowledge and understanding of generation $\mathrm{X}$ and $\mathrm{Y}$ respondents living in Indonesia about Malaysia, as their neighbor country. From the analysis carried out, Malaysia is a neighbor country that is familiar to most respondents. At the interpersonal stage, it is noticed that there is a stimulating trend in which even though the two countries are physically separated, it does not prevent the majority of them from establishing friendly relations with individuals from both countries. This case was acknowledged by the Gen X respondents who were interviewed who stated that they have many acquaintances from Malaysia and often visit this country for family and work matters (tebuual in 2016).

At the same time, apart from friendly relations, relationships are also manifested by economic factors, where the majority of those involved in this study stated that they have family members who live and work in Malaysia. Although the issue of foreign workers originating from Indonesia is often highlighted in a negative context by the media, if we look at the relationship between the people of the two countries, it is clear that there is a principle that shows that the relationship still exists between citizens of the two countries despite different factors. different. Gen X and Gen Y Indonesia admitting that Malaysia has much to contribute to the economy of the Indonesian people even though they 
Rohani Hj. Ab. Ghani, Abmad Sukri bin Abdul Hamid, Zulbilmi bin Paidi...

often looked negative $\mathrm{f}$ about Malaysia on several issues involving the interests of their country (Temubual 2016).

In the same relationship, when viewed from the general knowledge point of view about Malaysia, the majority of respondents, whether from Gen X or Gen Y categories, show a tendency to follow developments prevailing in Malaysia. Media coverage is among the main sources on which both generations are informed about Malaysia. However, there are slight differences between the two generations in terms of the type of media from which they source their information. Gen Y, as a generation that is more active and friendly with social media, shows a more tendency to follow and get information about Malaysia through these electronic media platforms, while Gen X, although the gap is not that far, is more dependent on traditional media such as newspapers and materials. reading.

At the same time, apart from the media, they also received information about Malaysia from friends and family who were residents in Malaysia. Here there is a slight difference between Gen X and Gen Y where the majority of those who obtain information through this kind of network consists of those in the Gen X category. This illustrates a trend that is currently prevailing as a generation that relies a lot on the media. Recently, Gen Y receives a lot of secondary information, namely through the distribution of social media that is impersonal compared to information directly through known relatives or friends. This type of media channel, 
although its coverage is rather extensive, does not give the impression of an impact compared to the information received and shared personally.

However, on average these two categories of respondents stated that the information obtained about Malaysia was positive. In this case, there is a slight difference between these two generations where Gen X has a more tendency to receive positive information about Malaysia, compared to Gen Y. This may also be related to the type of media mediation that is the channel of information received. Gen $\mathrm{X}$ who are more dependent on direct information is more exposed to information that is not polluted by various perceptions, while Gen Y who depend on social media may be more receptive to information that has been influenced by certain sentiments.

In the formula, there is a positive conception of the relationship between the two countries, namely Malaysia and Indonesia, from the point of view of the understanding of the Indonesian citizens involved in this study. For example, data shows that the majority do not have ancestors from Malaysia, but from another perspective, they show a tendency to follow developments that apply in Malaysia. More importantly, in both of these circumstances, no significant difference was found between the two generations.

At the same time, it cannot be denied that today various challenges have to be faced, especially among the new generation, where there is a perception gap that interferes 
Rohani Hj. Ab. Ghani, Ahmad Sukri bin Abdul Hamid, Zulbilmi bin Paidi...

with efforts to understand the similarities and differences that exist between two people of the same family and nation. Among the mechanisms that play a role in creating such disparities are open and uncontrolled media. In this scenario, it is not surprising why it is easier for the younger generation to focus on differences than similarities when judging things like this.

\section{ii.Differences in Understanding and Perceptions of Malaysia-Indonesia Relations Among Gen X and Gen Y}

In addition to looking at the stage of knowledge about Malaysia, this study also examines the distinction the view and perception of Indonesia against Malaysia intending to look the same no distinction in form between Gen X and Y. Indeed, as dealt with before this, on average there is no distinction of understanding of Malaysia between these two generations but in several aspects. After research, the aspects of understanding that show significant differences between the two generations involve issues that require in-depth research or understanding. This can be noticed if between the items that show significant differences are items that require extensive association and extensive reading. From this point of view, it is clear that Gen $\mathrm{X}$ has a deeper level of understanding about Malaysia as a result of their wider association, namely through friendship ties that cross national borders. Visits to Malaysia, as well as visits by colleagues from 
Malaysia to their countries, opened up many opportunities for conversation and added intimacy (Temubual In addition, Gen $\mathrm{X}$ also appreciates the spirit and meaning of the relationship between the two countries through appreciation of issues which often arise involving both countries. This will only appear in a person if they have an interest and are involved in activities to appreciate an issue through extensive reading and deep understanding.

Likewise, when analyzed in terms of perceptions of the Malaysia-Indonesia relationship, on average it is found that there are no significant differences between the two generations, but in several issues. Among the issues that show differences in terms of perception are related to respect for the people rather than the neighboring country. Gen Y shows relatively lower appreciation or respect for their Malaysian counterparts than Gen X. This perception is likely driven by Gen Y's lack of direct exposure to Malaysians. Their lack of knowledge about foreign country issues is influenced by various factors, including the role of local media which focuses more on local issues than outside the country (interview with expert group respondents 1, 2017). Their perceptions are heavily influenced by sentiments that are formed indirectly.

At the same time, differences in perception are also noted regarding the issue of migration involving job opportunities. Gen Y sees Malaysia as a country that has job prospects for them. From this perspective, Gen Y takes a 
Rohani Hj. Ab. Ghani, Ahmad Sukri bin Abdul Hamid, Zulhilmi bin Paidi...

more pragmatic attitude considering they are at an age that requires work. Gen X may also view this situation more critically by viewing the issue of Indonesian work that is often published in the media not only focused on the utilitarian aspect but also touches on humanity and services received by Indonesians working in Malaysia.

\section{CONCLUSION}

In conclusion, when viewed from the perspective of their understanding and perception of the same thing, it is found that there are slight differences between the two generations. Those belonging to the Gen $\mathrm{X}$ category were found to have a deeper stage of understanding and appreciation of the meaning of the relationship between the two countries, especially from the point of view of the relationship and link between citizens of the two countries. This matter is driven by the same historical experience by the older generation that ignited a higher sentimental value among them. Gen $\mathrm{Y}$, on the other hand, is more sensitive to issues that have a direct impact on them, such as work issues and emerging sentiments, rather than perceptions or media exposure. The influence of the media gives a great impression on the aggressive attitude of the Indonesian people when dealing with any issues related to Malaysia. In the context of a two-way relationship, a high understanding and positive perception can be an added value in Malaysia-Indonesia relations. In this regard, efforts to increase understanding and 
positive responses about the two countries need to be mutually encouraged for the common good.

It is undeniable that Malaysia-Indonesia relations are often overshadowed by national interests. This thing is also a thorn in the flesh in the relationship. However, national interests can also be relied on for Malaysia-Indonesia cooperation. Therefore, institutions that are close to Generation Y such as universities and colleges, newspaper and publishing companies, entertainment agencies, and nongovernmental organizations (NGOs) need to intensify efforts to provide knowledge and understanding among the younger generation who are not only in our country as well as in Indonesia. This step is important to develop a more positive perception of the two countries among the younger generation who are committed to strengthening IndonesiaMalaysia cooperation to create a win-win atmosphere for both countries.

\section{REFERENCE}

Ali Maksum \& Reevany Bustami. (2014). "Tension in Indonesia-Malaysia relations in the issue of the Pendet Dance", Malaysian Studies, Vol. 32, No. 2, 2014, pp. 4172.

ANM 2003/0008933, Bilateral Cooperation Agreement between Indonesia and Malaysia in the Field of Education and Culture, 26 January 1967, Bogor, 
Rohani Hj. Ab. Ghani, Abmad Sukri bin Abdul Hamid, Zulhilmi bin Paidi...

Indonesia (Original Copy on 31 May 1976, Kuala Lumpur).

Ahmad Nizar Yaakub. (2013). Dances with Garuda: MalaysiaIndonesia bilateral relations. Samarahan City: Universiti Malaysia Sarawak.

Azizah Kassim. (1998). International migration and its impact on Malaysia. In Mohamed Jawhar Hassan (Ed.). A Pacific Peace: Issues and Responses. Kuala Lumpur: Institute Strategic and International Security (ISIS).

Brackman, A (1963). Indonesian communism: A bistory. New York: Frederick A Praeger.

Bolton, et al, (2013). "Understanding Generation Y and their use of social media: a review and research agenda". Journal of Service Management, Vol.24, No. 3, pp. 245-26, 2013 [Oline]. Available: https://www. emerald insight.com/doi/full/10.1108/09564231311326987

Easter, D. (2004). Britain and Malaysia-Indonesia confrontation with Indonesia 1960-1966. London: Tauris Academic Studies.

Fitha Aini. (2012). "Freedom of the press in the context of Indonesia-Malaysia relations: Ambalat news reporting study in the Daily News (Malaysia) and Kompas (Indonesia), 2012 ASPIKOM Military Communication Seminar-Communication Studies 
Malaysia-Indonesia Bilateral Relations: Empirical Study on the Stage of....

Program, UPN "Veteran" Yogyakarta, Muhammadiah University, Jakarta.

Malaysian Foreign Affairs. (1966). Malaysian Foreign Ministry.

Kuala Lumpur: Wisma Putra.

Harrison, B. (1964). South-East Asia: A short history. London: Macmillan \& Co Ltd.

http://national.kompas.com/read/2010/08/30/19132967/ Malaysia.Takut.dengan.Indonesia. Access on 03/02/2017.

http://kabar24.bisnis.com/read/20170920/19/691530/ media-untungi-harga-indonesia-malaysia Access on $2 / 2 / 2017$.

Ismail Hussein. (1984). The history of the growth of the national language $k$ ita. Kuala Lumpur: Language and Library Council. Ministry of Education Malaysian Lessons.

Joseph Chinyong Liow. (2005). The politics of Indonesia-Malaysia relations, one kin, two nations. London: Routledge Curzon. Taylor \& Francis Group.

Kuneseelan a/1 Muniandy. (1996). Malaysia-Indonesia Relations 1957-1970. Kuala Lumpur: Language and Library Council.

Khazin Mohd Tamrin. (1987). Javanese in Selangor: Migration and Placement 1880-1940. Kuala Lumpur: Language and Library Council. 
Rohani Hj. Ab. Ghani, Abmad Sukri bin Abdul Hamid, Zulhilmi bin Paidi...

Lancaster, L. \& Stillman. (2002). D. When generation collide: Who they are why they clash, how to solve the generational purzle at work. New York: Harper Collins.

"Malaysia-Indonesia is very special" - Tun M. (2012). Malaysian Envoy, 9 November. Retrieved from http://www.utusan.com.my. Accessed on $23 / 3 / 2017$.

" Khairy apologizes for the issue of the Indonesian flag being reversed " (2017). Malaysiakini, 20 Aug. https://www.malaysiakini.com/sukan/392514.

Access on 22 February 2021.

Mak Jum Num. (2000). Domestic Politics and Conflict-Resolution in the South China Sea: China and the Spratly Disputes. Kuala Lumpur: MIMA.

Nik Anuar Nik Mahmud. (2000). Malaysia Indonesia Confrontation. Bangi: Publisher Universiti Kebangsaan Malaysia.

Focus group discussion with UIN students, Makassar, Indonesia, 2016.

Rohani Hj. Ab Ghani. Et.al. (2019). "Malaysia-Indonesia Relations Analysis Based on Knowledge and Understanding of Gen X and Y: A Survey Study". University Movement. Universiti Utara Malaysia: Center for Research and Negotiations. (S/O code 13368). 
Rohani Hj. Ab Ghani. (2014). "Malaysia-Indonesia Relations: The Malay Ocean Faces Challenges" working paper presented at the International Conference on "Islam and Muslim Societies in Southeast Asia: Towards a Better Future", 5-6 November 2014, Horizon Hotel, Panakkukang-Makassar, Indonesia.

Rohani Hj. Ab Ghani. (2013). Malaysia-Indonesia: Destined neighbors. Working paper presented at the 7th Malaysia-Indonesia International Seminar, Faculty of Social Sciences, Universiti Malaya, 22-24 October 2013.

Rohani Hj. Ab Ghani. (2012). Malaysia-Indonesia Relations: Overview. In Rohani $\mathrm{Hj}$. Ab Ghani (Ed.) MalaysiaIndonesia Some Points of Interest. Syntok: UUM Press.

RM Koentjaraningrat (1975). Introduction to the peoples and cultures of Indonesia and Malaysia. London: Cummings Publishing Company.

Saharuddin Mustafa. (2012, December 9). Measuring the value of nationalism. Malaysian Weekly. Retrieved from http://ww1.utusan.com.my. Access on 15/2/2017.

Sandro Gatra. (2012, December 17). Call Habibie a Traitor, SBY Values Zainudin Unethical. KOMPAS.com. Retrieved from http://nasional.kompas.com Access on $15 / 2 / 2017$ 
Rohani Hj. Ab. Ghani, Abmad Sukri bin Abdul Hamid, Zulhilmi bin Paidi...

figure id. (2020). "Hate for Indonesia is like ingrained, Malaysian politician mocks BJ Habibie wants to dissolve the Republic of Indonesia because of the case of Timor Leste" link from https:// figure.grid.id/read/412452238/kehatanpada-indonesia-bak- already-mendarah- meatpoliticians-Malaysia-scorned-bj-Habibie-wantdisbanded-nkri-due-timor-leste-case?page $=$ all, accessed on 10 March 2020.

http://www.sinarharian. com.my/plan/judging-generationy-1.79885 Access on 15/2/2017

Temubual with Prof. Dr. Ruhanas Harun, Universiti Defense Malaysia (UPNM), 2017.

Temubual with Prof. Associate Dr. Dato' Junaidi Abu Bakar, Sultan Idris University of Education (UPSI), 2017.

Interview with UIN lecturers, Makassar, Indonesia, 2016. Meeting with UIN students, Makassar, Indonesia, 2016. Malaysian envoy. (2018), 30 July.

Zainuddin Maidin (2012). "The similarities between BJ Habibie and Anwar Ibrahim". Utusan Melayu, 10 December. 